\title{
A Paradigm Proposal for the Determination of the Number of Marketplaces and Their Area Sizes
}

\author{
Gorkem Gulhan ${ }^{1}$ \\ ORCID: 0000-0003-2715-0984
}

\author{
Durdane Tay ${ }^{2}$ \\ ORCID: 0000-0002-9212-5737
}

\begin{abstract}
Marketplaces are decreasing day by day due to the rise of shopping center culture, changing transportation habits and the spread of supermarket chains. The reasons for that, are the changing cultural and economic characteristics as well as the inability to determine the number and size of marketplaces effectively in the districts. Marketplaces that fail to be established in the right place, in the right number, and in the right size are inadequate in terms of service scope. Thus, accessibility to food is damaged and reduced. Planning mistakes made in the access of food products to the society through public spaces indirectly harm the consumption and production processes of food. There are gaps in the literature concerning analytical methods on determining the number and size of the market places. In this study, the relationship between the number of marketplaces and their sizes is identified. The marketplace area per capita and the number of people per marketplace are calculated. Settlements with below the average values are then determined for the mentioned values and developing marketplaces in these regions are proposed. With the mentioned paradigm, it is possible to identify the necessary number and size of marketplaces in case of a future diversion.
\end{abstract}

Keywords: Marketplace, Denizli, location choice, regression.

\footnotetext{
${ }^{1}$ Assoc. Prof., Pamukkale University, E-mail: ggulhan@pau.edu.tr

${ }^{2}$ Graduate Student, Pamukkale University, E-mail: demiraydurdane@gmail.com

idealkent @ Kent Araştırmaları Dergisi (Journal of Urban Studies) 


\section{Pazaryerlerinin Alansal Büyüklük ve Sayılarının Belirlenmesinde Bir Yaklaşım Önerisi}

\author{
Görkem Gülhan ${ }^{3}$ \\ ORCID: 0000-0003-2715-0984
}

\author{
Durdane Tay ${ }^{4}$ \\ ORCID: 0000-0002-9212-5737
}

Öz

Pazaryerleri artan AVM kültürü̈, değişen ulaşım alı̧̧anllkları, sanal ulaşımın gelişmesi ve süpermarket zincirlerinin yayılması ile birlikte gün geçtikçe azalmakta ve küçülmektedir. Bu durum sadece değişen kültürel ve ekonomik özellikler ile ilgili değildir. Illçelerdeki pazaryeri sayılarının ve büyüklerinin etkin olarak belirlenememesi de pazaryerlerinin erişilebilirliklerini azaltmaktadır. Doğru yerde, sayıda ve büyüklükte belirlenemeyen pazaryerleri, hizmet kapsamı açısından yetersiz kalmakta, erişilebilirliği düşük olmakta ve yeterli sayıda kişiye ulaşamamaktadır. Böylece gıdaya olan erişilebilirlik zarar görmekte ve azalmaktadır. Gıda ürünlerinin kamusal alanlar üzerinden topluma erişiminde yapılan planlama hatalar dolayl olarak gıdanın tüketim ve üretim süreçlerine zarar vermektedir. Pazar yerlerinin büyüklükleri ve sayllarmin belirlenmesinde kullanilan analitik yöntemler ve niceliksel modeller konusunda literatürde boşluklar bulunmaktadır. Bu çalı̧̧ada, Denizli'de pazaryeri sayıları ve alansal büyüklükleri arasındaki ilişki çoklu doğrusal regresyon modeli yardımıyla bulunmuştur. Bu doğrultuda, ilçelerdeki pazaryeri sayılar ve alansal büyüklükleri ölçümlenmiştir. İlçelerdeki nüfus verileri de kullanılarak kişi başına düşen pazaryeri alanı ve pazaryeri başına düşen kişi sayıları hesaplanmıştır. Daha sonra anılan değerler açısından ortalama altında kalan yerleşmeler tespit edilerek bu bölgelerde pazaryerlerinin geliştirilmesi önerilmiştir. Önerilen yaklaşım ile farklı yerleşmelerde pazaryerlerinin sayı ve alan büyüklüğü ihtiyaçlarının belirlenebileceği değgrlendirilmektedir.

Anahtar Kelimeler: Pazaryeri, Denizli, yer seçimi, regresyon.

\footnotetext{
${ }^{3}$ Doç. Dr., Pamukkale Üniversitesi, E-mail: ggulhan@pau.edu.tr

${ }^{4}$ Lisansüstü Öğrenci, Pamukkale Üniversitesi, E-mail: demiraydurdane@gmail.com

idealkent @ Kent Araştırmaları Dergisi (Journal of Urban Studies) 


\section{Introduction}

Market areas are places where supply and demand meet in the most general sense. They are also the most important and first spatial points of accessibility to food for years. Since historical times, market areas have been the intersection point of producers and consumers. Shopkeepers provide residents with many of their needs, such as fresh and dried fruit, vegetables, daily necessities, clothing and household goods. A marketplace is defined as a place where a municipality permits sales of such goods, either one day of the week or every day (Eroglu, 1976, p.4). Markets have on the one hand enabled people to establish social relations and, on the other, served to meet needs and have led to the formation and emergence of central places. Markets established in rural areas are an especially important element of the product distribution and collection system, a fact which cannot be denied or ignored (Tunçel, 2006). Markets in rural settlements offer great opportunities for both market development and regional expansion of logistics (Deloitte Research, 2015).

In rural settlements and towns, marketplaces are usually open one day a week. However, fairs may conduct business for an entire season or just once a year. In larger urban settlements, people acquire some of their needs from grocery stores, clothing shops, bazaars, markets and supermarkets or larger shopping centers. In addition, they patronize weekly or other periodic neighborhood markets, established in different parts of the settlements at various times. Neighborhood markets have survived to the present day by adapting to changing shopping processes throughout history (Tunçel, 2003).

The first period for which data about marketplaces are available is when about four million of Turkey's inhabitants lived in cities and district centers. As can be seen in Table 1, an average of 65 markets and a total of 456 were established in provincial and district centers. Thus, there was one marketplace per 9,000 people. In 2005 , the population reached 70 million and the total number of markets approached 4,000. In other words, there was now one marketplace per 17,500 people.

Table 1. Number of weekly markets in Turkey in various periods according to their types

\begin{tabular}{lllll}
\hline Market Type/Year & $\mathbf{1 9 3 3}$ & $\mathbf{1 9 4 8}$ & $\mathbf{1 9 5 2}$ & $\mathbf{2 0 0 5}$ \\
\hline Commodity & 426 & 454 & 575 & 3084 \\
\hline Livestock & 25 & 47 & 57 & 565 \\
\hline Other & 5 & 5 & 13 & 186 \\
\hline Total & 456 & 506 & 645 & 3835 \\
\hline Weekly Average & 65 & 72 & 92 & 548 \\
\hline
\end{tabular}


Compared to prior periods, the number of marketplaces grew at a slower rate than the population. However, improvements in transportation and related conditions, the increase in the quantity and variety of products and the ease of distribution of goods compensate for this change. Improvements in transportation and related issues and ease of distribution of goods are directly related to the selection of location, number and other criteria regarding market areas.

\section{Literature Review}

The marketplace selection criteria of companies actually show features similar to the sales area location selections of retail companies. Since choosing a location for retail companies is a strategic and costly decision, firms evaluate many criteria, such as population, competition and economic characteristics (Karadeniz, 2009). The retail industry also favors locations that are easily accessible. In addition to all of these factors, the proximity of businesses to their competitors has a significant impact. Competition is one of the most important location selection criteria for the retail industry (Kayacan ve Yirmibeşoğlu, 2017). Determining the location of market areas is important for establishing a marketplace in a district. On the other hand, factors such as the climate, population, transportation and the structure of the economy are also important. Relevant laws should be taken into consideration as well, especially in recent times.

Companies try to manage the issue of location selection with information systems by developing technologies. Geographical Information Systems (GIS) is the most important and preferred of these information systems in the world. Bayar (2019) has used GIS to determine the most suitable locations to build shopping centers in Ankara. Given the potential of GIS, it turns out to be very useful for location selection (Cheng, \& Yu, 2007). Along with the GIS method, AHP and Delphi are also preferred methods for location selection (Hsu, \& Chen, 2007). AHP performs the ranking of potential sites and the importance levels of effective criteria in decision making with binary comparisons. And it is used in location selection (Omurbek ve Simsek, 2014). Demand capacity, spending capacity, ease of transportation, level of competition, central location and proximity to other locations are significant criteria for location selection.

Population growth, population density, market spread and the growth capacity of the city should be taken into consideration for the criteria to be used. 
The increase in number of the target customers brings along with it the growth of the marketplace and the diversification of products. The growth of the target customer base is also directly proportional to the size of the settlement areas.

Marketplaces vary considerably in terms of size, scale, practices and social and economic impacts on the settlements in which they are based. There may even be significant differences between the marketplaces established in the central district of a city (Çalışkan, 2007). Marketplaces assume different forms in different geographical environments, revealing very diverse spatial features throughout the world, from sections of streets and roads to squares and water surfaces. The differences observed in the forms and functions of marketplaces are closely related to multiple factors such as population size, purchasing power, socio-economic development level and urban development characteristics of the environment. In addition, with the effect of cultural values and local variations in economic and spatial use, marketplaces present different cultural geographical portraits in different places (Tümertekin ve Özgüç; 1998:126). In accordance with the needs of the population, marketplaces are formed with different qualities, quantities and at different times in the urbanization process (Aksoy, 2009). This is also reflected in the choice of location.

The location of marketplaces is determined by considering the needs of the population in the settlement in line with planning standards and principles. Standards related to the marketplace are specified: Marketplaces are designed to provide for the needs of a minimum of 2,500 people. In other words, a consumer turnover of 2,500 people is accepted as the minimum size needed for a market to survive (Göçer, 1984). The distance to the market should be at most $1.5 \mathrm{~km}$. The service area of a marketplace within a radius of $1.5 \mathrm{~km}$ is 700 hectares. The minimum market size should be 4,000-6,000 $\mathrm{m}^{2}$. Stand sizes in the area can be calculated as $10-15 \mathrm{~m}^{2}$ on average. The pedestrian path between stands should be at least $3 \mathrm{~m}$ long (Göçer, 1984).

Marketplaces in Turkey are not solely for shopping, but are also places that reflect Turkish society's customs and traditions. (Aksoy, 2009). The unique products of the markets, the marketing styles, the architecture, the clothing and the scents together form a regional identity. In this respect, markets are part of the culture of a country or society (Tümertekin ve Özgüç; 1998: 126). The places that best preserve the cultural characteristics of a society are marketplaces (Gavcar, Uçma, ve Köroğlu, 2006). However, as a result of cer- 
tain changes and developments, marketplace culture has started to disappear. This is not only due to cultural and economic changes. Decreasing accessibility to market areas and incorrect determination of their number and spatial size have been effective in the loss of marketplace culture. With the aforementioned problems and explanations as a point of departure, this study aims to determine the optimal number and area of marketplaces in the districts.

In the literature, there are various studies on the locations and sizes of marketplaces. However, there are several gaps in methodological approaches developed on a large scale by evaluating the relationship between them. The potential of the relationship between the number and sizes of marketplaces in a city to guide research and decisions regarding marketplaces should be evaluated. Partial, sectoral and heuristically evaluations are made today in determining marketplace requirements and sizes of settlements. However, the locations, sizes and number of existing marketplaces in the settlement and their relationships with the population may indicate the problem points. Efforts must be made to reduce the food access problem. The availability of nutritious and cheap food for all segments of society is much more important due to the climate change crisis Marketplaces are an effective way to provide access to food for people from all walks of life. Therefore, the correct determination of the number and spatial sizes of marketplaces results in an increase in accessibility of food. On the other hand, access to marketplaces must take into consideration urban transportation. Increasing accessibility and also spatial interactions are related to land use choices as well as transportation possibilities (Gülhan, Ceylan ve Oral, 2013; Gülhan, Ceylan ve Haldenbilen, 2014).

In this study, the relationship between the number of marketplaces and their size in rural districts in Denizli is revealed with the help of a multiple linear regression model. Accordingly, the number and size of marketplaces in the districts have been obtained. With the model devised within the scope of the study, it is possible to identify the districts for which the necessary numbers and sizes of marketplaces will need to be determined in case of a future diversion between population size. Instead of heuristic approaches, evaluations with surveys or hierarchical models (such as AHP, TOPSIS, DELPHI, etc.), the model established within the scope of the study may be used to determine where the marketplaces are inadequate, in which regions to establish more marketplaces, or to determine where the marketplaces are insufficient spatially. The number of marketplaces and their areal sizes have a relationship with each other, as well as with their pattern and distribution in 
other districts. The proposed model presents the opportunity to determine the numbers and areas that are contrary to the general pattern by making use of this relationship. There are many location choice models in the literature, but there is no paradigm that evaluates the aforementioned relationships.

\section{Methodology \& Study Area}

\section{Methodology}

A three-step method is developed to determine the required marketplace numbers and spatial sizes, and it is applied to the districts in Denizli. The data used in the developed method were obtained by measuring virtual data stores, on-site research and observation, published reports and studies on the subject, and by request from the administrative institutions. The size of the marketplace areas were measured using the map computation method. In Figure 1, the flowchart of the paradigm is given.

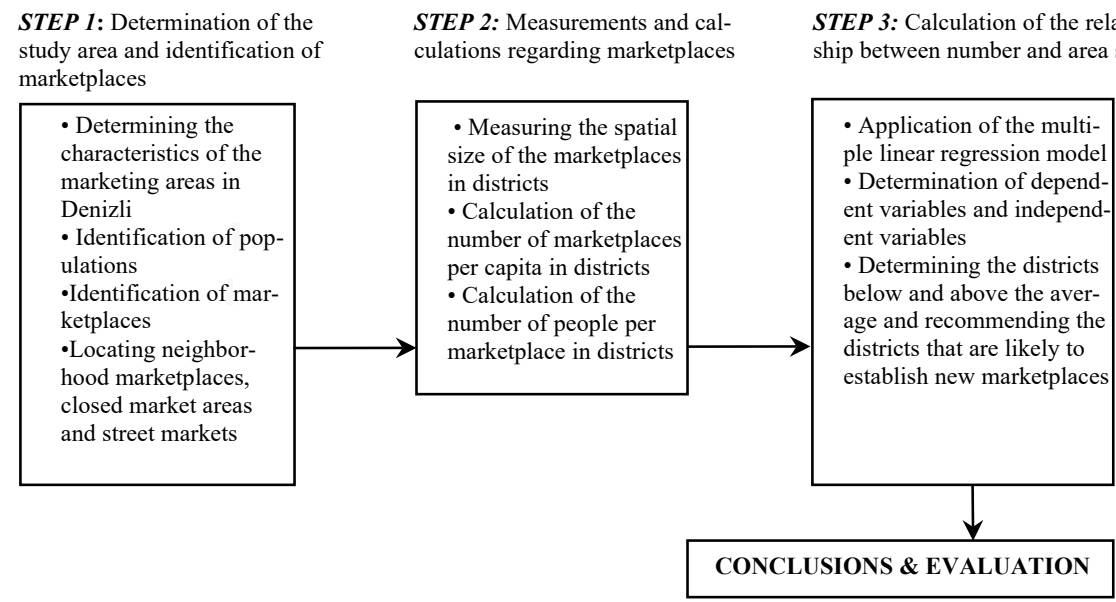

Figure 1. Flowchart of the mentioned paradigm

In STEP 1, the study area and its characteristics are determined. The demographic data and the positions of existing marketplaces are determined, mapped, and tabulated. Collecting the characteristics of the marketplaces and categorizations have been conducted for measurement. In STEP 2, the marketplaces in the districts are identified and their numbers are recorded in the tables. The size of each marketplace is measured on maps and tabulated. Then the average number of marketplaces per person in the districts and of people per marketplace are calculated. In STEP 3, multiple linear regression 
(MLR) analysis is performed after defining dependent and independent variables. MLR is a statistical method which is used to calculate the value of a variable based on the value of two or more other variables. The variable which we aim to forecast is called the dependent variable. Independent values are the variables which are utilized to calculate the dependent variable. The multiple linear regression formula is given in Equation (1).

$$
Y_{i}=\beta_{0}+\beta_{1} X i_{1}+\beta_{2} X i_{2}+\cdots+\beta_{p} X i_{p}+\epsilon
$$

\section{In Equation (1);}

\section{For $i=n$ observations}

$Y_{i}$ is the dependent variable,

$X_{i}$ is the explanatory variables,

$\beta_{0}$ is the $Y$-intercept (it is a constant term),

$\boldsymbol{\beta}_{p}$ is the sloping coefficient for every explanatory variable and the

$\boldsymbol{\epsilon}$ is the error term which is interpreted as residuals.

In a multiple linear regression analysis, $R^{2}$ is known as the multiple correlation coefficient of determination. An $\boldsymbol{R}^{2}$ value of $\boldsymbol{0}$ indicates that the regression line does not fit the set of data points at all, while a value of $\mathbf{1}$ indicates that the regression line is a perfect fit (Gunst \& Mason, 1980).

The $t$ statistic is the coefficient divided by its standard error. The standard error is an estimate of the standard deviation of the coefficient, the amount it varies across cases. It can be thought of as a measure of the precision with which the regression coefficient is measured.

As a result of the analysis, the significance levels and independent variables of the model are interpreted by considering the significance levels. Subsequently, districts above and below the average are identified, and those that are likely to need new marketplaces built or existing marketplaces expanded are proposed.

\section{Study Area}

Marketplace culture in Turkey has been very important throughout history and has shown continuous progress. Today, the need of the rapidly growing and developing population for marketplaces is increasing day by day. Open marketplaces, which were the only places where people could gather and exchange goods on a limited level in ancient times, are preferred today because they are easier for shopping, cheap, have a wide variety of goods and have goods for every budget (Aksoy, 2009). 
Denizli, with its location and marketplace culture rooted in the past, is one of the major cities of Turkey. It is the largest city in the Aegean region, after İzmir Denizli is one of Turkey's 16 most developed cities. Industry and commerce are evolving very fast, rendering it one of Turkey's most developed cities. The city has an excellent reputation in the US and EU markets for items such as towels, bathrobes and home textiles. As shown in Figure 2, Denizli has 19 districts connected to the center: Acıpayam, Babadağ, Baklan, Bekilli, Beyağaç, Bozkurt, Buldan, Çal, Çameli, Çardak, Çivril, Güney, Honaz, Kale, Merkezefendi, Pamukkale, Sarayköy, Serinhisar and Tavas.

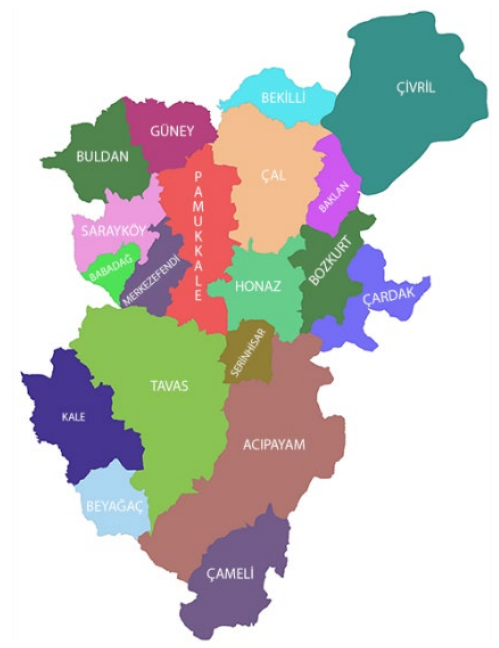

Figure 2. Districts of Denizli (Denizli Metropolitan Municipality, 2020)

The study area and the features of the mentioned area have been determined. The locations of the marketplaces in the study area have been mapped in detail with the help of data obtained from the relevant institutions and placed in a table. Marketplaces in Denizli are open seven days a week. Those markets meet the consumers' needs for fresh fruits, vegetables and clothing. Marketplaces can be established on streets, avenues or squares, depending on local geographical conditions. Marketplaces are viewed as a reflection of society in terms of their characteristics. Weekly markets are also important in terms of reflecting the cultural characteristics of Denizli. Marketplaces that used to be located on streets or in squares as street markets or producer markets in the past have since been turned into closed markets as a result of work carried out by the municipality in recent years. This facilitates the spatial placement of vendors and allows them to work more comfortably in cold and 
rainy weather. However, the closed market approach co-exists with the open markets of the streets and squares. The understanding of the marketplace in Denizli is that vendors provide the products they produce or buy as intermediaries to the public in closed or open areas on certain days of the week. It is possible to see producers and consumers from all strata of society in the marketplaces, from rural peasants to small tradesmen (Gavcar, Uçma ve Köroğlu, 2006). The presence of market traders and consumers from different segments sheds light on the market culture of Denizli. There are 19 districts connected to the center in Denizli, and each district has an open or closed marketplace. Districts and marketplace locations in Denizli are given in Figure 3.

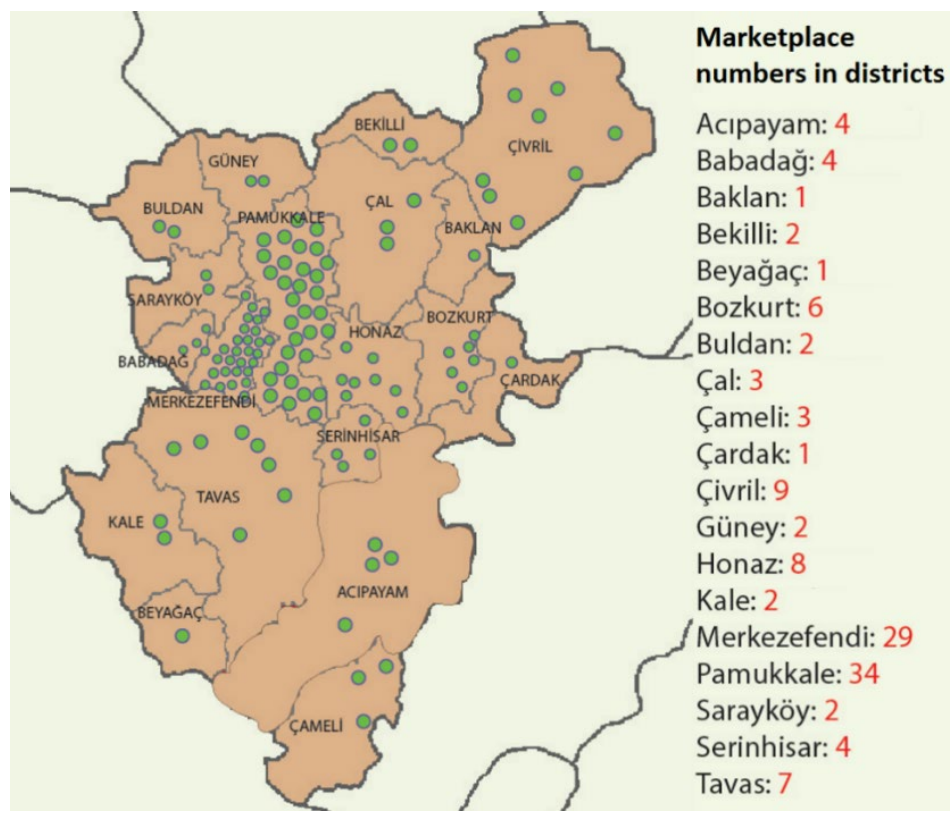

Figure 3. Districts and marketplace locations in Denizli (Denizli Metropolitan Municipality and Denizli Merkezefendi Municipality, 2018)

\section{Analysis}

\section{Data Collection \& measurement}

The locations of the marketplaces and their number on a district basis were obtained from the Real Estate Expropriation Directorates of the Metropolitan and Merkezefendi District Municipalities. The populations of the districts were obtained from the 2018 data of the Turkish Statistical Institute (TÜIK, 
2018). The areas of the marketplaces were obtained after determining their borders on maps.

Table 2 shows the weekly marketplace areas in Denizli. Data were generated by map base computation. With the help of the generated data, the amount of marketplace area per person and the number of people per marketplace were calculated. Figures 4 and 5 show the number of people per marketplace and the marketplace area per person.

Table 2. Marketplace Area Data for Denizli

\begin{tabular}{|c|c|c|c|c|c|}
\hline Districts & $\begin{array}{l}\text { Number } \\
\text { of } \\
\text { Marketplaces }\end{array}$ & Population & $\begin{array}{l}\text { Market- } \\
\text { place } \\
\text { area }\left(\mathrm{m}^{2}\right)\end{array}$ & $\begin{array}{l}\text { Market- } \\
\text { place } \\
\text { area per } \\
\text { person }\left(\mathrm{m}^{2}\right)\end{array}$ & $\begin{array}{l}\text { Number } \\
\text { of people per } \\
\text { marketplace }\end{array}$ \\
\hline ACIPAYAM & 4 & 55,648 & 12,016 & 0.21 & 13,912 \\
\hline BABADAĞ & 4 & 6,522 & 3,000 & 0.45 & 1,631 \\
\hline BAKLAN & 1 & 5,654 & 2,200 & 0.38 & 5,654 \\
\hline BEKİLLI & 2 & 7,065 & 4,960 & 0.7 & 3,533 \\
\hline BEYAĞAÇ & 1 & 6,903 & 1,400 & 0.2 & 6,903 \\
\hline BOZKURT & 6 & 12,788 & 3,898 & 0.3 & 2,131 \\
\hline BULDAN & 2 & 27,241 & 5,800 & 0.21 & 13,621 \\
\hline ÇAL & 3 & 19,259 & 4,450 & 0.23 & 6,420 \\
\hline ÇAMELİ & 3 & 18,256 & 11,000 & 0.6 & 6,085 \\
\hline ÇARDAK & 1 & 9,144 & 1,935 & 0.21 & 9,144 \\
\hline ÇIVRİL & 9 & 60,429 & 14,000 & 0.23 & 6,714 \\
\hline GÜNEY & 2 & 9,975 & 3,900 & 0.39 & 4,988 \\
\hline HONAZ & 8 & 33,184 & 9,000 & 0.27 & 4,148 \\
\hline KALE & 2 & 20,393 & 8,500 & 0.41 & 10,197 \\
\hline MERKEZEFENDİ & 29 & 302,213 & 116,779 & 0.38 & 10,421 \\
\hline PAMUKKALE & 34 & 344,065 & 143,989 & 0.41 & 10,120 \\
\hline SARAYKÖY & 2 & 30,768 & 8,300 & 0.26 & 15,384 \\
\hline SERINHHISAR & 4 & 14,430 & 11,501 & 0.79 & 3,608 \\
\hline TAVAS & 7 & 43,845 & 11,652 & 0.26 & 6,264 \\
\hline Average & & & & 0.36 & 7,414 \\
\hline
\end{tabular}

There is a marketplace for every 7414 people in Denizli. When the size of the market area per capita is examined, the average market area per capita is found to be $0.36 \mathrm{~m}^{2}$. There are 124 marketplaces in Denizli. The total market area is calculated as approximately $234,435 \mathrm{~m}^{2}$. As can be seen from Figure 4, the largest number of people per market is in the Sarayköy district and the smallest in the Babadağ district. There are 15,384 people per market in the Sarayköy district, while there are 1,631 people per market in the Babadağ district. 


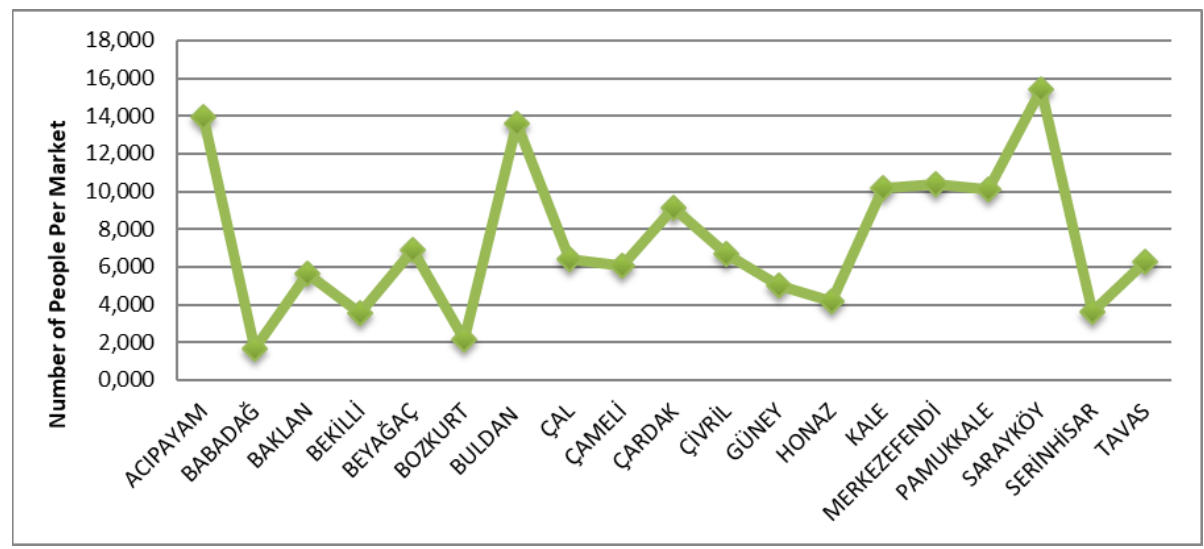

Figure 4. Number of People per Market (generated by the authors)

As can be seen from Figure 5, the amount of market area per capita is the highest in the Serinhisar district and the lowest in the Beyağaç district. In the Serinhisar district, there is a market area of $0.79 \mathrm{~m}^{2}$ per person, whereas in Beyağaç there is $0.20 \mathrm{~m}^{2}$ market area per person.

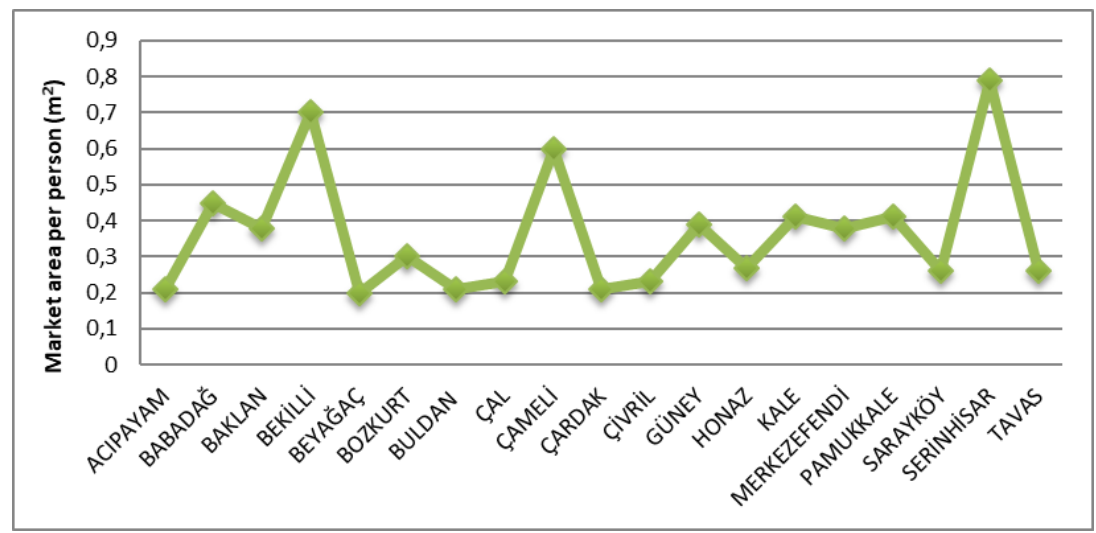

Figure 5. Market area per person $\left(\mathrm{m}^{2}\right)$ (generated by the authors)

\section{Performing Multiple Linear Regression Analysis}

The number of marketplaces in districts is indirectly related to many issues that districts face. The sociological structure, economic status, agricultural output, and geographical characteristics of the districts play a role in determining these numbers. It is expected that the number of marketplaces in districts will be higher the more spatially restricted the markets are. This 
section investigates whether there is a relationship in the marketplaces located in the districts of Denizli that accord with the aforementioned conditions.

The determination of this relationship is thought to be useful in regulating the number of marketplaces in the districts and evaluating the extent of their areas. A multiple linear regression model is used to investigate this relationship. The basic assumption of the model is that the number of marketplaces in the districts is related to population, market area size, market area per capita, and the number of people per marketplace.

In the model, the number of marketplaces (Y1) is the dependent variable, while independent variables are population (X1), market area (X2), per capita market area (X3) and the number of people per market (X4).

Before the model was tested, the Merkezefendi and Pamukkale districts, which are defined as central districts, were excluded from the category. These two districts show different geographical, demographic, economic, and spatial characteristics than the other districts that are not located in the Denizli countryside. For this reason, it is inappropriate to place them in the same category as the districts showing rural characteristics. The results of the multiple linear regression model made under these constraints are given in Table 3.

Table 3. Multiple linear regression model statistics results

\begin{tabular}{llll}
\hline$R^{2}$ & 0.9197 & & \\
\hline Independent variables & Coefficient & Standard Error & $t$-value \\
\hline Population $(X 1)$ & 0.0002 & 0.0001 & 4.0513 \\
\hline Marketplace area $(X 2)$ & -0.0003 & 0.0002 & -1.3134 \\
\hline Market area per capita $(X 3)$ & 7.1766 & 2.3241 & 3.0879 \\
\hline Number of people per marketplace $(X 4)$ & -0.0003 & 0.0001 & -3.8221 \\
\hline
\end{tabular}

Positive $t$ values indicate that, as the population increases, the number of marketplaces increases according to the model. Negative $t$ values indicate that as the market area grows, the number of markets in districts decreases. The reason for this is the inverse ratio between area size and number.

\section{Developing Marketplace Suggestions}

Marketplace opportunities in districts below the average per capita market area, as well as those above the average number of people per marketplace, should be investigated. In order to determine the aforementioned values, the averages are taken and the districts that meet both conditions are marked in Table 4. 
Table 4. Districts crossing average thresholds simultaneously

\begin{tabular}{lll}
\hline Districts & $\begin{array}{l}\text { Market Area Per Per- } \\
\text { son }\end{array}$ & Number of People Per Marketplace \\
\hline Acıpayam & $\underline{\mathbf{0 . 2 1 6}}$ & $\underline{\mathbf{1 3 , 9 1 2}}$ \\
\hline Babadă & 0.460 & 1,631 \\
\hline Baklan & 0.389 & 5,654 \\
\hline Bekilli & 0.702 & 3,533 \\
\hline Beyağaç & 0.203 & 6,903 \\
\hline Bozkurt & 0.305 & 2,131 \\
\hline Buldan & $\underline{\mathbf{0 . 2 1 3}}$ & $\underline{\mathbf{1 3 , 6 2 1}}$ \\
\hline Çal & 0.231 & 6,420 \\
\hline Çameli & 0.603 & 6,085 \\
\hline Çardak & $\underline{\mathbf{0 . 2 1 2}}$ & $\underline{\mathbf{9 , 1 4 4}}$ \\
\hline Çivril & 0.232 & 6,714 \\
\hline Güney & 0.391 & 4,988 \\
\hline Honaz & 0.271 & 4,148 \\
\hline Kale & 0.417 & 10,197 \\
\hline Sarayköy & $\underline{\mathbf{0 . 2 7 0}}$ & $\underline{\mathbf{1 5}, 384}$ \\
\hline Serinhisar & 0.797 & 3,608 \\
\hline Tavas & 0.266 & 6,264 \\
\hline AVERAGE & $\mathbf{0 . 3 6 3}$ & $\mathbf{7 , 0 7 8}$ \\
\hline & &
\end{tabular}

When the average values in Table 4 are examined, the districts crossing the limits of both average thresholds at the same time are found to be Acıpayam, Buldan, Çardak, and Sarayköy. Therefore, it is recommended to research the potential for the development of the numbers or area sizes of marketplaces in these districts. In other words, the marketplace opportunities and numbers in the aforementioned districts should be developed in terms of consumption and production potentials and accessibility opportunities.

\section{Discussion \& Conclusion}

Methods for determining the numbers, locations and sizes of marketplaces and sales areas using similar techniques in accessing food are generally evaluated together. These are methods that deal with each subject separately, even if they are in-depth. When the studies carried out in this field are examined, it is seen that hierarchy-based methods such as AHP, DELPHI and TOPSIS are frequently used for determining the locations of marketplaces. On the other hand, heuristic approaches are generally developed by administrations and planners regarding how many marketplaces should be in the districts 
and what their size should be. In some cases, decisions are made based on survey results obtained from market research. However, the sizes and numbers of marketplaces are not unrelated issues; on the contrary, they are completely related. Therefore, there is a need for a holistic method in which they are evaluated together. The original difference of this study is that it produces a model/approach in which the numbers and sizes of marketplaces in the districts are evaluated with a more holistic approach than previous studies.

It is determined that marketplaces are open seven days a week in provinces and districts. In these marketplaces which are open only one day a week, vendors meet the consumers' needs for fresh fruits, vegetables and clothing by providing products produced or purchased as intermediaries. In the marketplaces, there are producers and consumers from all walks of life, from rural peasants to small tradesmen.

Marketplaces established weekly in Denizli may be located on streets or squares, depending on geographical conditions. In the past, the marketplaces established on streets or in squares as street markets or only as markets where producers or farmers sell directly to customers, rather than going through middlemen. This facilitates the spatial placement of vendors and allows them to work more comfortably in cold and rainy weather. The relationship between the numbers of marketplaces and their sizes in the districts of Denizli has been found with the help of a multiple linear regression model. By using district population data, the market area per person and the number of people per marketplace are calculated. There are 124 marketplaces in Denizli. The total market area is calculated as approximately $234,435 \mathrm{~m}^{2}$. There is a market for every 7,414 people in Denizli. There is an average market area of $0.36 \mathrm{~m}^{2}$ per person. The market area per capita is the highest in the Serinhisar district and the lowest in the Beyağaç district. The highest number of people per market is in the Sarayköy district and the lowest is in the Babadağ district. It is determined that the number of marketplaces increased as the population increased, and the number of marketplaces decreased in districts with larger market areas. Necessary concrete projects for regional producers should be developed with detailed needs analyses and site selection decisions for market areas. Marketplace opportunities and numbers in Acipayam, Buldan, Çardak, and Sarayköy districts should be evaluated in terms of consumption and production potentials and accessibility opportunities.

As a result, the marketplace area per capita and the number of people per marketplace were calculated using the population data in the districts. Later, settlements below and above the average on a district basis were determined 
in terms of the aforementioned values. It has emerged that new marketplaces should be developed in these areas.

The numbers and sizes of the marketplaces in the districts are always changing because the economy, population and needs of cities are always dynamic and constantly changing. Therefore, it is thought that in similar situations, in different geographical areas but in similar places, the question of how many marketplaces there should be in the districts and whether their areal sizes are sufficient or not can be answered with the help of the model proposed within the scope of this study. Future spatial and numerical changes for Denizli can also be planned much more effectively.

The location choices of marketplaces should be taken into account in terms of maintaining sustainability and developing urban and rural agriculture. At this point, the evaluations of the food and consumer organizations in the city regarding the locations and sizes of the marketplaces should be taken into account. The study developed a model that contributes to greater access to food. At this point, it should be taken into account that increasing accessibility of food is not only related to the number and areal size of the marketplaces. Especially for increasing the accessibility of marketplaces, the importance of urban transportation is dominant. The work to be done on issues such as public transportation facilities, parking facilities, traffic congestion levels and pedestrian / bicycle transportation are related to access to food. Especially in future studies, considering that urban transportation relations are related to the numbers and sizes of marketplaces, models can be produced in this context. Social class dynamics should also be included in the parameters in the approaches of future studies.

\section{References}

Aksoy, Y. (2009). Pazar yerlerinin Şehir Planlaması standart ve ilkeleri yönünden incelenmesi: İstanbul İli Bakırköy İlçesi Örneği. Çukurova Üniversitesi Sosyal Bilimler Enstitüsü Dergisi, 18(2), 26-39.

Bayar, R., (2005). CBS yardımıyla modern alışveriş merkezleri için uygun yer seçimi: Ankara. Coğrafi Bilimler Dergisi.3(2), 19-38.

Beyhan, H. C., Gizem, E. R. E. N., ve AKTUĞ, B. (2020). Perakende market lokasyonları için CBS tabanlı Çok Kriterli AHP yöntemi ile optimal yer seçimi analizi: İstanbul Örneği. Afyon Kocatepe Üniversitesi Fen ve Mühendislik Bilimleri Dergisi, 20(6), 1032-1050.

Cheng, E., Li, H., \& Yu, L. (2007). A GIS approach to shopping mall location selection.Building and Environment, 42(2), 884-892. 
Çalışkan, V. (2007). Kentsel mekân kullanımındaki farklılıklar üzerine bir yaklaşım: Bursa ve Çanakkale'nin periyodik (haftalik) pazarlarından örnekler. Doğu Coğrafya Dergisi, 12(18), 49-78.

Denizli Metropolitan Municipality, Real Estate Expropriation Directorate. (2019).

Denizli Merkezefendi Municipality, Real Estate Expropriation Directorate. (2019).

Dheena, P., Mohanraj, G. (2011). Multicriteria decision-making combining fuzzy set theory, ideal and anti-ideal points for location site selection. Expert Systems with Applications, 38(10), 13260-13265.

Eroğlu G.(1976). Kurtuluş Semt Pazan Araştırması. İTÜ Mimarlık Fakültesi, Bitirme Tezi.

Gavcar, E., Uçma, T., ve Köroğlu, Ç. (2006). Seyyar pazar esnafinın sorunları ve çözüm önerileri (Muğla İli Örneği).

Gulhan, G., Ceylan, H., ve Haldenbilen, S. (2014). Evaluation of residential area proposals using spatial interaction measure: case study of Denizli, Turkey. Procedia-Social and Behavioral Sciences. 111, 604-613.

Gunst, R.F., Mason, R.L. (1980) Regression analysis and Its Applications, Marcel Dekker, New York.

Gülhan, G., Ceylan, H., ve Oral, Y. (2013). Ulaşım talebinin belirlenmesinde erişebilirlik ve arazi kullanım modellerinden yararlanılması, 10. Ulaştırma Kongresi. İMO, İzmir, $26-29$.

Göçer, O. (1984).Şehirlerde ticaret alanları. İTÜ Kütüphanesi Sayı: 1286, Gümüşsuyu.

Hsu, P. F., \& Chen, B. Y. (2007). Developing and implementing a selection model forbedding chain retail store franchisee using Delphi and Fuzzy AHP. Quality and Quantity, 41(2), 275-290. https://doi.org/10.1007/s11135-006-9004-z

Karadeniz M.(2009). The Importance Of Retail Site Selection In Marketing Management And Hypothetical Approaches Used In Site Selection, 5(3), 79-90

Kayacan T. \& Yirmibeşoğlu F. (2017). Site selection criteria for sports retail sector: Istanbul Case. Current Urban Studies, 5(3), 290-304

Omurbek, N. \& Simsek, A. (2014). Selection of Online Shopping Site Based on Analytic Hierarchy Process and Analytic Network Process Methods. Journal of Management and Economics Studies, 22, 306-327.

Tabari, M., Kaboli, A., Aryanezhad, M. B., Shahanaghi, K., \& Siadat, A. (2008). A new method for location selection: A hybrid analysis. Applied Mathematics and Computation, 206(2), 598-606.

Tunçel, H. (2003). Anadolu şehirlerinde semt pazarları: Elazığ Örneği. Journal of SocialScience, 49. Tunçel, H. (2006). Türkiye'nin karsal pazar bölgeleri. Ankara Üniversitesi IV. Ulusal Coğrafya (Avrupa Birliği Sürecindeki Türkiye'de Bölgesel Farklılıklar) Sempozyumu (25-26 Mayıs 2006) Ankara. Bildiriler kitabi s. 63-72, Ankara.

Tunçel, H. (2018). Türkiye'deki periyodik pazarlarm smıflandırlması. TÜCAUM30. Yil Uluslararası Coğrafya Sempozyumu. Bilecik Şeyh Edebali Üniversitesi, Fen Edebiyat Fakültesi, Coğrafya Bölümü.

Tümertekin, E; Özgüç N. (1997). Beşeri Coğrafya, Çantay Kitabevi, İstanbul TÜIK (Turkish Statistical Institute), 2018. Denizli District Population Data. 